\title{
HISTORIAS IMPÚDICAS. \\ EL PROGRAMA ERÓTICO DE BIGAS LUNA
}

Gonzalo M. Pavés

Universidad de La Laguna

Data recepción: 2017/01/25

Data aceptación: 2017/04/20

Contacto autor: gpavores@ull.es

ORCID: https://orcid.org/0000-0002-7183-4454

\section{RESUMEN}

Tras el fracaso de su debut cinematográfico, Bigas Luna se encontró en una situación financiera delicada. Acuciado por las deudas y sin trabajo, en 1977 encuentra una salida cuando se le ofrece a posibilidad de dedicarse a la realización de una docena películas cortas en súper $8 \mathrm{~mm}$ de temática eróticas con el fin de ser comercializadas por correo. Fue ésta la primera vez que el cineasta catalán tenía la oportunidad de llevar a la pantalla parte de las ideas que sobre el erotismo defendió a lo largo de toda su filmografía. Este artículo busca sintetizar qué pensaba el cineasta sobre la relación del sexo y el cine, un pensamiento que fue depurando y transformando a lo largo del tiempo, y en segundo lugar, ver como este pensamiento se concretó en esta serie de cortometrajes que más tarde reuniría bajo el título de Historias impúdicas.

Palabras clave: Bigas Luna, cine español, erotismo, cortometrajes, sexualidad

\section{ABSTRACT}

After the failure of his cinematographic debut, Bigas Luna found himself in a parlous financial situation. Beset by debts and short of work, he was given a fresh start in 1977, when he was invited to make a dozen short erotic films on super $8 \mathrm{~mm}$ for distribution by post. It was the first time that the Catalan director had the opportunity to bring to the screen some of the ideas he posited on eroticism throughout his film-making career. This article seeks to synthesise Luna's thoughts on the relationship between sex and the cinema, thoughts that he would refine and revise, and to assess how this thought took shape in this series of shorts, which he would bring together and release years later under the title Historias impúdicas.

Keywords: Bigas Luna, Spanish cinema, eroticism, short films, sexuality

Tengo tanta imaginación que, como decía Manet, a veces envidio a la gente que no la tiene Bigas Luna, 2001

Para la realización de su primer largometraje, adaptación de una de las novelas del detective Pepe Carvalho de Manuel Vázquez Montalbán, Bigas invirtió el dinero que hasta entonces había ganado con sus trabajos en el campo de diseño y la publicidad. Estrenado en el cine Regio Vistarama Palace de Barcelona, el 30 de noviembre de 1977, Tatuaje fue un auténtico fiasco comercial. Ignorada por la crítica, la vida comercial de la película fue corta - apenas llegaron a treinta mil las personas que acudieron a verla - y desalentadora - la recaudación fue sólo de unos diecisiete mil euros'. Acuciado por las deudas y sin trabajo, al realizador catalán se le ofreció en- 
tonces la posibilidad de dedicarse a la producción de películas cortas de temática "sexis" con el fin de ser comercializadas por correo. El momento era propicio. España estaba en esos convulsos años dando los primeros pasos para dejar atrás la dictadura franquista y la censura oficial, aunque todavía seguía vigilante, había comenzado a abrir la mano para permitir la representación en el cine de ciertos temas que hasta entonces habían estado prohibidos. Así, a lo largo de 1977, Bigas Luna rodó una docena de cortometrajes eróticos que no solo fueron una tabla de salvación para su delicada situación económica, sino también fueron decisivos desde un punto de vista profesional porque, como él mismo confesaba: "yo aprendí de alguna manera la técnica del cine haciendo estas doce películas. Me las montaba, lo hacía todo yo"z. De alguna manera, estas obritas de puro destape fueron una suerte de escuela de aprendizaje donde el joven realizador pudo familiarizarse con los rudimentos básicos del arte cinematográfico, al tiempo que le permitieron trasladar a la pantalla, de una manera muy germinal e incipiente, algunos de los temas que continuaría desarrollando a lo largo de toda su carrera posterior. Ahí radica su importancia. No tanto por la calidad de esta producción, sino por el papel que jugaron en el desarrollo de Bigas Luna como artista y director. Con este artículo se pretende exponer en primer lugar las líneas maestras de su concepción del erotismo, para a continuación examinar cómo este ideario se vio reflejado en estos cortometrajes.

\section{Erotismo versus pornografía}

Erotómano para unos, pornócrata para otros, no se descubrirá nada nuevo, si se afirma que en el universo creativo de Bigas Luna, el sexo tuvo siempre tal peso que se convirtió en una de las constantes temáticas más consistentes de toda su filmografía. Si se repasa el conjunto de su producción cinematográfica con detenimiento parece evidente que el realizador catalán era además un creador especialmente dotado para alumbrar imágenes cargadas de un insólito y bello erotismo que además, todo hay que decirlo, entendía de una forma muy particular y reconocible. Vital y hedonista, nunca ocultó su gusto por la sensualidad, aunque se rebelaba cuando tildaban su cine como morboso. "Yo no soy nada morboso, el morbo no me gusta: siempre hay en él un deseo de muerte. Me entusiasma la transgresión, pero todo mi erotismo, toda mi sensualidad, apuntan a

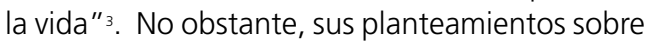
este tema no siempre fueron los mismos. Al igual que ocurre en su filmografía, su concepción y consideración del erotismo y la pornografía evolucionaron, fue variando con el transcurso de los años ${ }^{4}$. Nunca su pensamiento permaneció estancado, sino más bien todo contrario. Bigas gustaba de modelarlo de manera continua, sustrayendo capas, añadiendo otras, incurriendo a veces en contradicciones que nunca ocultaba, que cultivaba, sazonaba y degustaba. En sus primeras entrevistas parecía disfrutar, con impostada inocencia, del revuelo que había provocado entre los espectadores el rasurado en primer plano del pubis de la prostituta protagonista de Bilbao (1978) o el cánido cunnilingus en Caniche (1979).

En este fiero erotismo de sus primeros filmes hay un poso que conecta con el surrealismo. Como ocurría en este movimiento de vanguardia, el concepto de erotismo de Bigas Luna es feroz y radical, una fuerza subversiva, un arma privilegiada para manifestar y volver eficaz su rechazo al sopor en el que vivía instalada la burguesía. "Si el público ha mostrado tanto temor y desconfianza ante el surrealismo es porque está sembrado de trampas. Y está sembrado de trampas porque es ambivalente" ${ }^{5}$, porque para los artistas surrealistas - de los que Bigas es deudor ${ }^{6}$ - detrás de cualquier acto, de cualquier situación, detrás de los objetos más cotidianos subyace siempre un elemento sexual. Al igual que ellos se recreaba trastornando las significaciones normalmente atribuidas a las cosas, a los objetos cotidianos, disfrutaba mezclándolas, fagocitándolas, digiriéndolas, excretándolas. No es casual que la técnica los ready-made, tan querida por el grupo surrealista, consistiera precisamente "en desviar a los objetos de sus funciones en suma: pervertirlos, subvertirlos"7. En la provocación había pues liberación. En esta primera etapa negra y "rabiosamente autoral", el cineasta denostaba el erotismo de papel cuché porque su imaginario sexual nada tenía que ver con la seda y la lencería fina, su morbo era, según sus propias palabras, "algo mucho más marrano y grotesco"8. Pese a 
ello, tampoco consideraba que su cine pudiera ser calificado como pornográfico.

En esto soy muy clásico. Para mí el porno son pollas en acción, personajes que se corren (aunque nunca lo hacen de verdad, lo simulan muy bien), fornicaciones para todos los gustos, etc. $Y$ yo en cambio prefiero una salchicha. Sugiere y es más excitante. Me interesa que un objeto simple - un pez, una salchicha, un cepillo de dientes, una máquina Braun - cobren un sentido erótico, adquieran una capacidad de excitación (...). De todas formas sigo pensando que lo verdaderamente erótico en el film son los objetos. A mí me interesa coger cosas cotidianas y transformarlas en fetiches eróticos ${ }^{9}$.

En cualquier caso nunca hubo en Bigas Luna, al menos en esta primera etapa de su carrera, un rechazo frontal de la pornografía. Simplemente no le interesaba. Pensaba que era un género "cojonudo, pero absolutamente marginado"10, un tipo de cine subestimado en el que, por sus bajos presupuestos y salvando el caso, según su opinión, de El Imperio de los sentidos (Ai no korîda, Naghisa Oshima, 1976), apenas se habían hecho obras realmente interesantes. "Reducir la pornografía a porquerías me parece injusto con el género" "11, sentenciaba años más tarde. Para él lo porno tenía más ver con el realismo absoluto, por su características este tipo material estaba más cerca del reportaje fisiológico que de la ficción cinematográfica, "por eso no me dice mucho, porque no permite la elaboración, la mentira"12. Como les sucede a los compañeros de la fundición donde trabaja Horty, el protagonista de La camarera del Titanic (1999), Bigas en realidad no estaba interesado por la descripción de la verdad, ni por la fidelidad del relato a los hechos. Al joven Horty se les presta atención porque con la ficción todos se adentran, inquietos y curiosos, en un espacio íntimo, reservado, que estaba fuera del alcance de sus miradas. A Bigas Luna, que era un voyeur nato, le apasionaba transgredir la privacidad de los otros, irrumpir en sus espacios secretos para desvelar lo que está oculto y normalmente no se ve. Pero él no era un cronista, sino un insólito y sorprendente fabulador. Por esta razón no le gustaba lo evidente, lo explícito, por lo que tenía de cotidiano y vulgar. Por eso no le cautivaba el cine porno - el "cine médico" como gustaba definirlo -, porque es un cine ob- sesionado con la descripción gráfica. Lo que sí le atraía, por el contrario, era articular sus historias y delinear a sus personajes a través del sexo. Una de sus obsesiones siempre fue captar ese momento preciso en el que la pulsión sexual, algo tan básico y primario, "se transforma en algo más, cuando su finalidad no es solo la continuidad de la especie"13, es decir, ese instante crucial en el que sexo se convierte en el acto intelectual más inspirado del hombre:

Los perros no saben de erotismo, conocen solo la sexualidad. El gusto y el erotismo son la consecuencia directa del refinamiento. El hombre y la mujer hacían el amor como perros. Cuando ella se dio la vuelta y quiso mirarse en los ojos de su partenaire, ese día se inventó el erotismo, en el momento en que esa mirada pasó a ser lo más importante. (...) Cuando ella quiso ver los ojos de su hombre, de su amor, esa mirada fue más excitante que el hecho de estar follando. A partir de ahi la mirada entra en funcionamiento: un tirante que cae, la curva de un cuello, un ligero sudor que traza en la piel un reguero brillante, los ojos que se entornan y se cierran; en fin, nace el erotismo y explota en toda su grandeza ${ }^{14}$.

El erotismo para él estaba más relacionado con la psicología que con el funcionamiento de los órganos genitales, mucho más con el deseo que con el placer ${ }^{15}$. Un erotismo que transfiguraba el sexo gracias a la imaginación "pues ella vuelve palpables las formas de deseo" ${ }^{16}$. Por esta razón, la mirada en su cine constituía el eje central y vertebrador de su concepto del erotismo:

El erotismo es un privilegio de la mente, es un acto intelectual. Los animales no saben del erotismo. El erotismo es mirada, es cabeza y pensamiento, es un patrimonio del ser humano. Es el aspecto intelectual más popular. El erotismo es practicado por todo el mundo. Hay gente que dice que no tiene imaginación, pero en cambio saben lo que es el erotismo, un ejercicio de imaginación. Me gusta, es una gran riqueza y creo que hay ser muy respetuoso con el erotismo ${ }^{17}$.

Bigas se movía como pez en el agua en el mundo preorgásmico, allí donde trabaja la fantasía y no los genitales. Es en los prolegómenos y no en el éxtasis donde Luna encuentra la fuente de inspiración para sus más lúcidos y potentes momentos cinematográficos. "El erotismo es invención, 
variación incesante. El sexo es siempre lo mismo. La posibilidad y riqueza narrativa del erotismo es infinita, mientras que la de la pornografía es muy limitada" ${ }^{18}$. Es finalmente, como escribía Octavio Paz: "sexualidad socializada y transfigurada por la imaginación y la voluntad de los hombres"19. Por esta razón al realizador lo que más le interesa del erotismo es su capacidad de explotar la sugerencia, la evocación, jugar a dilatar las energías desatadas por el deseo, embridarlo para conducirlo a voluntad, dosificando sus arrebatos, ralentizando sus frenesís. "Si todo ocurre a nivel del deseo, entonces la imagen descubre las virtudes de la alusión, de la espera, del sueño que abre los ojos del territorio de imaginario erótico en los que la realidad se somete a la imaginación individual y colectiva" ${ }^{20}$. Si el erotismo era poesía, la pornografía sólo era un documental. Frente a la necesidad vital de reproducirse, se contraponía el goce, la recreación estética, el placer de mirar sin ser visto. "Se piensa demasiado a menudo en el erotismo como carnalidad, como sexo, mientras que es patrimonio del intelecto", afirmaba el realizador para a continuación sentenciar: "Los animales de hecho ignoran el erotismo, porque no tiene imaginación" ${ }^{21}$. De esta manera, como bien señala André Compte-Sponville, el hombre se convierte en un animal esencialmente erótico, el único que sitúa el deseo por encima del placer, el único que lo cultiva, lo recrea y no se conforma con satisfacerlo con la primera bestia que se le aparece. Esto es lo que lo separa de los animales, esta es la razón por la que ni "el sexo ni la muerte son propiamente humanos. Pero el erotismo y los funerales sí"22.

\section{Un Erotismo para un cine lunar}

Podría sorprender y parecer incluso incongruente que Bigas, en muchas de las entrevistas que concedió durante su vida, se acorazara y se mostrase tan paradójicamente reticente a contestar a preguntas sobre sexo: "De sexo no se habla", decía con un punto de solemnidad y suspicacia. "El sexo es tan íntimo como la fe religiosa" ${ }^{23}$. Para él, el sexo mundano, crudo, sin cocinar, sin el condimento que le confiere la ficción no tenía ningún interés. La sexualidad debía estar recluida en el secreto de las alcobas. En cambio, cuando se le preguntaba acerca del potencial narrativo que el sexo tenía, entonces sí se expresaba en términos mucho más locuaces y receptivos. En sus manos el sexo era un vehículo prodigioso para contar las historias que le interesaba, pero no para hablar de sexo. "El sexo, la sexualidad" reflexionaba "son un algo inmenso que contiene una multiplicidad de interpretaciones" 24 . Bigas Luna tenía, por supuesto, una muy personal y sugestiva forma de entender el erotismo que, de manera empecinada, no se cansó de plasmar a lo largo de toda su obra fílmica. Tenía claro que el fin último de las ficciones cinematográficas que construía era "dar salida a nuestras fantasías y obsesiones, para hacer cosas que en la sociedad civilizada no encajarían" ${ }^{25}$, alineándose de este modo con el pensamiento de George Bataille cuando aseveraba que el "deseo del erotismo es el deseo que triunfa sobre la prohibición" ${ }^{26}$. Así ante la ley se oponía seductora la posibilidad de la transgresión, y el cineasta siempre prefirió caer en la tentación de romper con lo conveniente y con las reglas preestablecidas: "El sexo es subversivo; ignora las clases y las jerarquías, las artes y las ciencias, el día y la noche; duerme y solo despierta para fornicar y volver a dormir" 27 . Es cierto que su forma de entender el sexo evolucionó y se transformó con el curso de los años. Sus primeras cintas son obsesivas, claustrofóbicas en forma y en contenido, cerradas, oscuras, y poco a poco, a partir de Lola (1986) y más claramente con Las edades de Lulú (1992), el cambio le lleva a concebir unas películas más luminosas, de colores cálidos que destilan vida, sensualidad, una sexualidad desbordante que mana a borbotones de sus imágenes.

Nunca consideró a Bilbao y Caniche como obras auténticamente eróticas, sino más bien todo lo contrario. Pensaba que podían provocar erotismo en gente muy elemental, porque en estas películas el sexo sólo era un instrumento más para diseccionar en el alma de sus personajes: "Para alguien que pueda verlas con la mente normal y desarrollada intelectualmente yo creo que son películas antiéroticas, son películas muy frías, muy duras, donde el sexo es un vehículo para explicar otras cosas, y sólo muestro la parte negra, dura y fría del sexo" ${ }^{28}$. Fue ésta una etapa fílmica dominada por lo racional, por el concepto, por el desprecio hacia todo aquello que fuera humano, dominada por la especulación y el juego 
intelectual "tanto en el proceso creativo personal como en la relación con el espectador, por el que no sentía el más mínimo interés" ${ }^{29}$. Con los años y la experiencia Bigas, al tiempo que modera este provocador discurso inicial, se acerca más a su público. En su trilogía roja o ibérica el creador se muestra más pasional, más instintivo. Lo humano pasa a constituir un elemento primordial sustituyendo la agresividad por la ironía. Se trata de un punto de inflexión en su carrera como cineasta, un momento en el que el Bigas bravucón y arrogante se torna más vital, sensual y hedonista, más mediterráneo. Pareciera como sí a partir de esta nueva etapa la sexualidad hubiera adquirido para él otro sentido, más luminoso, como si fuera una respuesta a la muerte, o más bien en una suerte de afirmación de la vida. Es entonces cuando la sensibilidad de Bigas Luna apunta hacia un erotismo a ras de suelo, terrenal, grotesco, tosco, cutre y camionero, un erotismo cuyos frutos florecerán en los rincones más inesperados, un erotismo que hundía sus raíces en la tierra. No era un erotismo de perfumes y bellas veladuras, sino un erotismo jadeante, sudoroso, y con vello impúdico y salvaje en las axilas. En esta segunda etapa se impone un "realismo amacarrado y una simbología pedestre, aunque no falten las pequeñas porciones de psicoanálisis y surrealismo" 30 .

Bigas lo tenía claro. La gran relación entre el cine y erotismo se fundamentaba en la mirada. Le apasionaba mirar, escrutar lo íntimo, lo secreto, adentrarse hasta desvelar lo oculto entre las sábanas y el cine le proporcionaba una herramienta eficaz para invadir ese espacio privado y mostrarlo en una gran pantalla sin adornos, sin tapujos. De esta forma, erotismo y cine se vuelven inseparables en su poética, están ligados precisamente por la mirada. Bigas Luna, además, establecía una curiosa correspondencia entre la forma oval que guardan el ojo y el sexo femenino. Uno paralelo a la tierra, el otro apuntando hacia el cielo, marcando de modo sutil el nacimiento y la muerte del ser humano, su apertura a la luz, pero también su postrero suspiro ${ }^{31}$. Salimos al nacer, sostenía el cineasta, por un orificio ovalado vertical que es la vagina, y al morir, lo último que ve el ser humano es cómo se apagan, en sentido horizontal, cada uno de sus ojos. Su fascinación por el acto de mirar y todas las potencialidades que encierra le llevó a construir el complejo armazón de una de sus películas más brillantes desde el punto de vista de su estructura narrativa, Angustia (1987). Una propuesta cinematográfica audaz donde al espectador se le invitaba a dejarse llevar por una espiral donde el espacio ficcional se desplegaba en un juego de múltiples espejos y en el que un psicópata obsesionado con arrancar los ojos de sus víctimas era uno de los protagonistas.

Para Bigas el origen del erotismo estaba, por lo tanto, en aquella seminal mirada que dos amantes primitivos intercambiaron cuando copulaban por primera vez frente a frente. Con aquel sencillo gesto, según él, los seres humanos abrieron la puerta a todo un arsenal de estímulos, inspiraciones, provocaciones, mitos, fantasmas y fantasías que dieron una dimensión humana a la sexualidad. Es significativo que en sus filmes, de forma recurrente, las mujeres cabalguen a sus parejas mientras se aman y el contacto visual entre ellos sea casi permanente. Cuando este no existe o desaparece, o los hombres se imponen a sus parejas por la espalda, en su cine suele ser indicativo de la decadencia del amor o de la pasión. Así le ocurre, por ejemplo, en Lola a la protagonista interpretada por Ángela Molina y a su marido francés, el sensible y educado Robert. En su primer encuentro ella se sienta a horcajadas sobre él y Bigas, para hacer partícipe al espectador de la pasión que se ha desatado entre ellos, filma la mayor parte de la escena centrando la atención en el rostro de Lola que directa y turbadoramente mira a la cámara. Más tarde en el relato, cuando la seguridad y el equilibro del matrimonio se ve sacudida por la irrupción del antiguo novio de Lola, ésta le hará el amor a su esposo evitando que se crucen sus miradas y cerrando los ojos de manera significativa.

Tampoco es un hecho fortuito que en todas sus películas los personajes se miren, se observen, se acechen. Son los prolegómenos de una pasión que adivinan cercana. Como una constante en la obra cinematográfica de Bigas Luna, aparece la figura del espectador anhelante, casi siempre masculino, que contemplan en la distancia como sus "presas", sensuales y despreocupadas, se contonean al son de la música. Su presencia en su filmografía se puede rastrear hasta el psicópata voyeur interpretado por Ángel Jové en Bilbao. Sumido en la oscuridad, refugiado en la distancia, 
oculto entre los demás espectadores del sórdido local, Leo asiste fascinado, en este filme, al febril y voluptuoso espectáculo de striptease de la prostituta. En escenarios y situaciones parecidas también se encuentran los personajes de Robert en Lola, Raúl en Jamón, Jamón (1992) y Godoy en Volaverunt (1997). A todos ellos les baila el ojo, tembloroso de ansiedad y lujuria mal disimulada, ante los lúbricos cuerpos cimbreantes de las mujeres que desean. En Las edades de Lulú, por ejemplo, cuando la protagonista y Pablo celebran su boda bailando con insolente felicidad, uno de los invitados al banquete no puede evitar, pues la envidia le corroe, preguntar a su acompañante mientras señala a Lulú: "Oye, ¿esa amiga tuya es una cachonda?". También algo así ocurre en La teta y la luna (1994), donde las miradas enamoradas de Teté y Miguel rivalizan por conquistar el amor de la bella Estrellita el día en el que ella danza por primera vez para los habitantes del pueblo.

Encontramos asimismo personajes que, desde un sofá o un sillón, ralentizan el acto sexual, lo contemplan o subliman el deseo. Así cuando Pablo, en su primera noche con Lulú, decide permanecer sentado ante la joven y ordenarle que se quite los zapatos, se baje las bragas y se desabroche el botón de su camisa para liberar su cuello, su intención no es otra que dosificar unos minutos su ánimo enardecido. Al final de esta historia, Lulú se verá envuelta en otra escena en la que también tres ávidos espectadores asisten, desde un sofá rojo de vulgar escay, a un espectáculo privado de sadomasoquismo "netamente español". Años más tarde, en la que habría de ser su última película DiDi Hollywood (2010), el cineasta planteó una situación parecida. En este caso, la protagonista llevada por su deseo de triunfar y convertirse en una gran estrella en la industria del cine, se ve obligada a ceder ante los caprichos de un maduro empresario farmacéutico cuyo grupo invierte mucho dinero en el mundo del espectáculo. Nuevamente aquí el hombre se coloca sentado ante la mujer que se encuentra de pie ante él. Mientras da sorbos a una cerveza zaragozana Ámbar 1900², con voz firme y sin apartar un segundo la vista sobre la muchacha, va indicándole a DiDi lo que tiene que hacer. Primero le pide que se quite la blusa, a continuación las bragas, para más tarde invitarla a sentarse, abrir las piernas y descubrir su sexo florecido. Después de contemplarla un segundo, se levanta y se agacha detrás de ella, le desabrocha el sujetador y abre con escrupulosa precisión la cremallera de su falda hasta dejar desnuda toda su espalda. Es entonces cuando vierte la cerveza sobre su cuerpo para a continuación, satisfaciendo un impulso fetichista, lamer el líquido desde sus omoplatos hasta el arranque amelocotonado de sus nalgas.

Otra curiosa intervención de la figura del espectador en el imaginario erótico de Bigas Luna se encuentra vinculada a la fantasía de compartir pareja con una tercera persona. Sin ir más lejos Pablo en Las edades de Lulú engaña a su esposa, vendándole los ojos, para que se acueste con su propio hermano. Él orquesta la escena, no participa, allana el camino y se divierte asistiendo al sórdido encuentro incestuoso. El trío, como fantasía, era para Bigas un delirio maravilloso, pero era consciente de la delicada geometría variable que la sostenía. Siempre hay uno de los participantes que, en un momento u otro, se ve desplazado a un segundo plano propiciando el nacimiento de emociones y sentimientos encontrados. En Caniche la tensión latente que subyace en el peculiar y sórdido triángulo formado por Eloisa, su hermano Bernardo y su perro Dani, se evidencia cuando ella embadurna su sexo con miel para solazarse con la lengüita de su mascota mientras Bernardo, impotente y celoso, los contempla desde la puerta de la habitación. Lo mismo le ocurre a Benito, el desenvuelto y presuntuoso protagonista de Huevos de oro (1993) que, tras quedar lisiado en un accidente de automóvil y marchar a Miami con Ana, su fogosa amante latinoamericana, ve con desesperación como ya no puede "empalmarse sin permiso" y su jardinero lo ha sustituido con clamoroso éxito en la cama. Más dura y desgarradora es otra de las secuencias que filmó para Las edades de Lulú en la que, esta vez, participaban Lulú, Pablo y la travesti Ely encarnada por María Barranco. Los tres personajes, después de una opípara cena en un restaurante y tras unos escarceos previos entre Lulú y Eli en el sillón trasero del coche, deciden proseguir más cómodamente los tres juntos en un local "especial". Allí, entre risas y sorbos de champán, comienzan a besarse con Pablo, pero poco a poco Ely va cayendo en la cuenta de que, su presencia allí es circunstancial, que sólo ha sido un detonante para encender la pasión del matri- 
monio. "Oye, Lulú... qué posesiva. Deja algo para las demás" reclama infructuosamente la transexual que, cuando comprende que la han dejado fuera del juego, triste y amargamente se consuela masturbándose en un rincón de la habitación.

Todo este conjunto de creencias en torno al erotismo y la sexualidad, Bigas lo fue decantando poco a poco, a lo largo del tiempo, dejándolo a veces a la intemperie, volviendo sobre él para eliminar con una poda minuciosa sus ramificaciones más tortuosas. A finales de la década de los setenta, toda su concepción sobre el erotismo estaba por hacer, de ahí el interés que suscita el análisis de los cortos "sexis" que dirigió tras el fracaso de su primera película.

\section{El programa erótico festivo de Bigas Luna}

En 1977 Bigas Luna tuvo la primera oportunidad de volcar todas estas ideas en un conjunto de cortometrajes de corte erótico que, rodados en el casero formato súper $8 \mathrm{~mm}$, tenían un objetivo muy claro: explotar el ansia y la curiosidad sexual de los españoles tan duramente reprimida a lo largo de cuarenta años de nacionalcatolicismo.

Después de Tatuaje hice una serie de películas en super-8, de estas pseudo-pornos. No lo eran en absoluto porque entonces no se podía ni enseñar el coño, en todo caso se les podría llamar "sexis". Las distribuíamos por correo. Fue una experiencia cojonuda, muy divertida y además muy difícil. Teníamos que hacer películas que teóricamente hicieran trempar pero en las que no se podía ver nada. Aún guardo los papeles de censura; porque las mandábamos a censura para que las aprobaran. Ahora las veo como películas cómicas ${ }^{33}$.

En esta aventura le acompañó Fernando Amat, propietario de la mítica Sala Vinçon de Barcelona y promotor del arte del diseño tanto nacional como internacional. Según él se trataba de producir películas cortas "de destape, eróticas, pero intentando que la gente las comprara como cine porno, con lo cual nos inventamos una marca que era CINE PROMO ${ }^{34}$. En las cajas de cine súper $8 \mathrm{~mm}$, si no prestabas atención, tú lo leías como cine porno" ${ }^{35}$. Para su filmación contó además con un equipo formado, entre otros, por Pep Cuxart como jefe de producción, con la que enton- ces era su esposa, Consol Tura - que se encargó del vestuario -, Rosa Fernández como ayudante de dirección, los directores de fotografía Tomás Pladevall y Pedro Aznar, y un reparto compuesto por Linda Lay, Pilar Matus, Maica Tihenen, Rosa Raich, Carmen García, Sarima, Jennie, Nicola Brown, Susana Lee, Rosa García, Diana Domken, Silva Sue y Roberto Nani. Según el propio cineasta, el negocio de estas películas "sexis" fue "un fracaso porque las nuestras eran las únicas que no se vendían. La gente las devolvía porque no gustaban. En el fondo aquello era - en buen o mal sentido - cine underground" ${ }^{36}$. Pasados los años y quizás tratando de rentabilizar la fama que de erotómano se había creado a su alrededor gracias al impacto de sus dos siguientes películas, Bilbao y Caniche, en abril de 198437, todas estas películas - excepto una, la titulada Mona y Temba ${ }^{38}-$, fueron compiladas y comercializadas bajo el título Historias impúdicas. Programa erótico de Bigas Luna en formato video $\mathrm{VHS}^{39}$. Esta selección se ordenó y estuvo compuesta por los cortometrajes Coctel internacional, La deportista, La roulotte, El espejo, El desayuno, ParísHollywood, La millonaria, El ídolo, La mora, Ski y Las guitarristas. Con una duración aproximada de diez minutos cada uno, no existía entre ellos ninguna hilazón argumental que los conectara, pero eso sí, prometían a sus potenciales espectadores momentos de excitación, provocación y sensualidad reunidos en una "película erótica muy especial y divertida".

Dominada por una estética marcada y decididamente kitsch y cutre, la producción de estos cortometraje deja entrever la escasez de medios y la precariedad del formato utilizado para su creación. A pesar de la popularidad alcanzada en el ámbito doméstico y familiar, no era el súper $8 \mathrm{~mm}$ un formato muy dúctil y agradecido. La calidad de la imagen y del sonido resultante era un elemento difícil de prever. Desde luego que era mucho más barato que rodar, por ejemplo, en $16 \mathrm{~mm}$, pero también no menos es cierto que el resultado final estaba condicionado por factores que, como el proceso de revelado, estaban fuera del control de los cineastas. Bigas ya había coqueteado con este formato antes de lanzarse de forma profesional a la realización cinematográfica, cuando todavía sus principales intereses estaban en el campo del diseño y de la pintura. 
En estas primeras incursiones, caseras, Bigas hizo todo tipo de experimentaciones, desde el plano fijo hasta la doble exposición, experiencias que más tarde utilizó en Mona y Temba y las películas compiladas bajo el genérico título de Historias impúdicas. Sin embargo, no tienen un estilo común. La planificación y puesta en escena varían mucho en estas películas. En algunos, como en los cortos que abren y cierran el programa en la versión videográfica, predomina la simpleza expositiva, mientras que en las nueve historias restantes se constata una mayor "complejidad" y "elaboración". El planteamiento de Coctel internacional y Las guitarristas es muy similar y, por la posición que ocupan en la edición VHS, actúan de algún modo como un prólogo y un epílogo a todas las demás. Además de ser las dos únicas películas de la serie en las que no se cuenta nada, toda la acción consiste en la presentación, a modo de carnal catálogo de muestras, de un ramillete de bellezas femeninas que, al ritmo de melodías repetitivas ${ }^{40}$ y con más desparpajo que gracia, se van desprendiendo de sus ropas hasta quedar totalmente desnudas. Estas dos cintas están resueltas con un único plano fijo que se abre sobre un austero y minimalista espacio cinematográfico. En Coctel internacional las jóvenes hacen su número de striptease en una habitación de paredes de tonos rosáceos, presidida por el retrato pictórico de una muchacha sonriente ataviada con uniforme escolar - obra que por cierto Bigas Luna reutilizará para decorar las paredes de la casa que Leo comparte con María en Bilbao -, flanqueada por dos columnas de orden impreciso y un pequeño banco en el centro. En el caso del corto que cierra Historias impúdicas su sobriedad es mucho mayor. Antes de los títulos de crédito de Las guitarristas, Bigas utiliza varios insertos donde se suceden la roseta, el mástil, el puente y el clavijero de una guitarra española. Tras mostrar el nombre de la productora y el título del filme, el objetivo de la cámara se abre a una habitación despojada de todo adorno, salvo por la enigmática presencia, en el suelo y apoyado contra la pared, del vernáculo instrumento musical. En términos generales, en el resto de las películas lo que prevalece es una realización muy funcional, donde abundan los primerísimos planos de objetos y diferentes partes del cuerpo femenino - especialmente de sus senos -, y en la que, en ocasiones, se abusa de la reiteración de planos y posiciones de cámara. Desde el punto de vista de las estructuras narrativas hay dos cortos - concretamente los titulados La mora y El ídolo - que destacan sobre los demás, cintas en las que se puede entrever, de una forma todavía muy embrionaria, algunos de los modos y maneras que caracterizaron el estilo posterior del cineasta. En el primero de estos casos, por ejemplo, Bigas Luna se vale del montaje alterno para jugar, no sin un punto de humor, con las expectativas de su público. La historia arranca cuando una motorista rubia vestida de cuero "secuestra" a una joven musulmana en mitad de una calle y ante los ojos atónitos del que parece ser su novio norteafricano. Éste emprende una vana persecución de la motocicleta que, lentamente, desaparece en medio de la confusión del tráfico. Indiferentes a todo, las dos jóvenes terminan solazándose y consolándose mutuamente en el apartamento de la motera, mientras en paralelo se nos muestra al infatigable muchacho en su desnortada persecución por las calles de la gran ciudad. El corto concluye de modo inesperado cuando la muchacha rubia alertada por un ruido familiar que llega desde el exterior, sale al balcón y desde allí contempla con impotencia como el supuesto pretendiente de la joven mora se da a la fuga con su moto. Mucho más interesante, por su complejidad estructural es El ídolo, porque en ella ya aparece lo que Ramón Espelt considera una de las obsesiones temáticas más reiteradas en la filmografía de Bigas Luna: el cuadro dentro del cuadro ${ }^{41}$. En esencia lo que se cuenta es cómo una pareja - la única en realidad de toda la serie -, excitados por la proyección de un filme casero de un striptease masculino protagonizado por el mismo joven, terminan ahítos de orgasmo y placer. Se plantea por tanto una historia de voyerismo en la que se superponen, al menos tres miradas que, sin comunicarse entre ellas, conviven en tres niveles narrativos distintos y dispuestos en una estructura de anillos concéntricos. El primero, el más básico, estaría ocupado por el propio espectador situado fuera del espacio compositivo. En el segundo se encontraría la pareja que contempla entusiasmada el filme que se proyectan, y finalmente, en el anillo central estaría situado el joven que, embutido en una hornacina y sin desprenderse de las gafas de sol, se desnuda pro- 
vocativamente desde la pantalla. El ídolo de esta manera podría entenderse como un apunte, un esbozo rápido y muy incipiente, de la lúcida construcción que Bigas Luna llevaría a cabo diez años más tarde en una de sus películas más inquietantes y sugestivas: Angustia. En este juego de reflejos que multiplican el espacio ficcional quizá también se podría incluir los cortos titulados El espejo, La millonaria y Paris-Hollywood ${ }^{42}$. En los tres sus protagonistas, en un ejercicio de narcisismo enardecido, utilizan la luna de los espejos en sus juegos de autoerotismo.

Aunque en su momento estos cortos fueran englobados dentro del género porno, en realidad no comparten con él el carácter franco y abierto de sus imágenes. Vistos hoy en día resultan más eróticos que otra cosa, sus planteamientos son ingenuos, casi inocentes, algo que revela "que las designaciones y representaciones en torno al sexo también se transforman (y se acentúan tras situaciones de replanteamiento político)" ${ }^{43}$. Es probable que el incierto y convulso contexto social e histórico en el que estaba sumido el país en aquellos años impidiese a Bigas Luna transitar con más firmeza el camino de la pura pornografía. No hay que olvidar además que la censura franquista siguió actuando, de modo oficial y al menos sobre el papel, hasta la aprobación de la Constitución de $1978^{44}$. Este factor explicaría que en estas cintas prepondere la sugerencia más que la exposición directa, aunque también esta podría ser una opción estética del propio artista. El cineasta se cuida, en cualquier caso, muy mucho de presentar las situaciones de un modo explícito. Al contrario de lo que ocurre en la pornografía convencional no existen primeros planos de los genitales en acción, no hay eyaculaciones ni penetraciones descrita con fisiológica minuciosidad, todo lo más algún pudoroso plano detalle de un pubis - El espejo -, de una nalga - femenina en París-Hollywood, masculina en El ídolo - o de un desangelado y flácido sexo masculino - El ídolo. Los orgasmos femeninos son representados sin aspavientos, se producen casi de manera imperceptibles - en El espejo, por ejemplo, se hace evidente cuando la muchacha cae rendida sobre un tablero de ajedrez derribando todas sus piezas. Un cunnilingus es levemente sugerido en La mora mientras en la banda sonora se escucha el tema Mustapha interpretado por Bob Azzam. Es hacia las zonas erógenas donde Bigas Luna dirige fundamentalmente la mirada de sus espectadores; así en cuanto le es posible acerca el objetivo de la cámara a los senos de sus protagonistas para mostrarlos agitados por el deseo y la lujuria. En el segundo de los cortos titulado La deportista, por ejemplo, donde se describe la tabla de ejercicios diaria nada más despertar de una lozana muchacha, aprovecha los momentos en los que la joven se monta, desnuda de cintura para arriba, en una bicicleta estática o se coloca ante una máquina de masaje, para ofrecernos en un amago de montaje analítico una sucesión de planos detalles de sus pechos vibrando y balanceándose con voluptuoso frenesí.

El universo erótico que propone Bigas Luna en sus Historias impúdicas es, por tanto, un universo masculino y heterosexual en el que la figura femenina es el centro del espectáculo, el blanco de tiro para el ojo de un viril espectador. Salvo en el caso de El ídolo y quizás en La roulotte donde aparecen encarnando al dueño mafioso del peculiar burdel, el guardaespaldas y el cliente voyeur -, el papel de los hombres en estos relatos es mínimo, de hecho sólo aparecen en La millonaria - el marido durmiente -, en La mora - el novio musulmán que roba la moto - y también se intuye su presencia en el fuera de campo al final de La deportista. Se trata además de un mundo cuyo armazón se construye a partir de las fantasías varoniles más tópicas, donde no hay diálogos y abunda los personajes solitarios y en el que, cuando coinciden varios personajes, apenas hay comunicación entre ellos más allá de un gesto o una mirada.

Varias son las líneas temáticas que son abordadas por Bigas Luna en esta serie; de todas ellas, quizá la más básica y evidente sea la del voyerismo. En este aspecto estaba siendo coherente con su propio credo erótico que, como hemos dicho en anteriores epígrafes, nunca dejó de repensar y pulir en toda su vida. Los cortos de Historias impúdicas son, en este sentido interesantes, porque nos muestra su primer acercamiento cinematográfico a este tema al que tanto tiempo dedicó. En esencia toda película de corte erótico o pornográfico se apoya en la innata curiosidad humana y juega con el placer escópico que genera en el espectador la posibilidad de inmiscuirse, sin ser 
descubierto, en la vida privada de los demás. En toda la serie, por tanto, el público del que nosotros formamos parte actúa desde el fuera de campo, como un agente necesario para la acción. Bigas Luna no quería una audiencia pasiva, sino todo lo contrario; con estos filmes el cineasta catalán buscaba hacer trempar a su público. Precisamente la figura del mirón es la protagonista de uno de los cortos más singulares: La roulotte. Al inicio se nos presenta un solar vallado y sembrado de caravanas en el extrarradio de una gran ciudad que resulta ser un peculiar burdel regentado por hombres de apariencia mafiosa. Hasta allí llega en su coche un hombre alto, rubio y vestido con una gabardina que le llega hasta las rodillas. Después de escoger en un catálogo a la señorita que más le agrada, es conducido hasta el remolque número cinco. En su interior, tras unas rejas, una joven desnuda, con zapatos de tacón y con un collar de cuentas alrededor de su cuello inicia una seductora danza acompañada por el canto y el ritmo trepidante de tambores africanos, y el contrapunto furioso del barritar de un elefante. La mujer aparece como la encarnación de la Naturaleza, como una fiera enjaulada que, desde el interior de su prisión, desata todas sus armas de seducción para encandilar al expectante macho. Durante todo el relato el hombre, cómodamente sentado en un sofá, se contenta con recrear su mirada con el primitivo y sensual bamboleo de su torso, sus pechos turgentes y sus caderas. Sólo en el plano final, cuando la cámara se sitúa en el exterior de la roulotte para ver cómo ésta se tambalea enérgicamente, a un lado y al otro, indicando que el cliente y la muchacha han pasado a la acción.

Otro de los temas principales de Historias impúdicas es el autoerotismo, una actividad que, en estas películas, siempre es practicada por mujeres. Ejercitan los placeres onanistas las jóvenes de La deportista, El espejo, El desayuno, La millonaria, La mora y Ski. El cineasta representa estos momentos de íntimo entretenimiento con sumo cuidado, con planos pudorosos en los que, tomados desde cierta distancia, se sugiere más de lo que finalmente se muestra. El tratamiento de algunos de estos pasajes no está exento de un humor imaginativo en el que se puede reconocer la mano del cineasta. Pintoresca y divertida es, por ejemplo, la situación que se describe en el filme titulado Ski donde una muchacha (Linda Lay), sola, aburrida y con la pierna derecha escayolada hasta el muslo, siente de pronto la imperiosa necesidad de travesear cuando comienza a proyectarse una sucesión de diapositivas de diversas personas en la nieve practicando saltos y esquí alpino. Junto a esto también encontramos que Bigas Luna, con una pulsión que recuerda los modos de la vanguardia surrealista y que se puede rastrear en toda su obra cinematográfica, trastoca el uso y la función de algunos objetos cotidianos para desvelar su carácter sexual. En este caso, la cinta más representativa es La millonaria, película que por cierto reaprovechará también en Bilbao. La "trama" arranca, de modo insólito e inesperado, con unas breves escenas del inicio del famoso filme Raíces profundas (Shane, George Stevens, 1953 ${ }^{45}$. Mientras se escucha el diálogo de fondo de la película en un televisor se nos presenta a una pareja en el lecho conyugal de madrugada. Él dormido le da la espalda a su pareja, ella rubia, con rulos en el pelo y vestida solo con un picardías negro trasparente, está desvelada y contrariada. Hastiada se levanta, se desprende de la lencería y de su tocador coge un espejo de mano, una estola de piel blanca, unos bombones, una caja dorada de cigarrillos "Benson and Hedges» y un secador. De regreso a la cama, mientras ve la televisión y devora bombones, activa el secador y lo coloca entre sus muslos. El aire caliente hará el resto. Los guiños cinéfilos abundan en Históricas impúdicas. En este mismo corto, sobre el tocador de la millonaria, se puede distinguir un portarretrato con una fotografía de Marilyn Monroe, pero las referencias al mundo del cine son más abundantes y claras en las bandas sonoras que el propio Bigas eligió para cada uno de estos cortometrajes. Además del tema principal de la película Borsalino (Borsalino, Jacques Deray, 1973) utilizado en Coctel internacional, se recurrió también a la música de Sólo ante el peligro (High Moon, Fred Zinnemann, 1952) en El ídolo y a la de Las noches rojas de Harlem (Shaft, Gordon Parks, 1971) en El desayuno ${ }^{46}$.

En su obra cinematográfica Bigas Luna cultivó su sitofilia con la constancia y paciencia de un buen agricultor. Desde luego no ha sido el único. Muchos directores, antes y después que él, han utilizado la relación que existe entre el mundo culinario y erotismo. A lo largo de la historia del 
cine, esta pulsión sitofílica se ha presentado de muy diversas maneras. Quizá la forma más recurrente ha sido la de subrayar el poder afrodisiaco que tradicionalmente se les ha conferido a ciertos alimentos. Así parece que le ocurre a la protagonista de La millonaria puesto que al combinar la ingestión de un par de suculentos bombones con la exposición al aire caliente de su secador, tiene efectos inmediatos en su libido. El espíritu gastroerótico del cineasta, sin embargo, se muestra de un modo mucho más explícito en el filme titulado El desayuno. En la cocina de una casita de montaña, una joven rubia se prepara a comenzar el día con buen pie. Tras calentarse la leche y poner un LP en un tocadiscos, se sienta en la mesa para disfrutar de su primera comida. Mientras suena el tema de la película Shaft, mezcla de soul y funk, toma galletas con mermelada hasta que, víctima de un inesperado ardor, se desabrocha su camisa a cuadros para mostrar lo que oculta su generoso escote. Transportada por un irresistible y lúbrico arrebato unta sus pechos con mermelada de fresa y melocotón, chupa sus dedos embadurnados y termina casi desnuda, sólo con medias, masturbándose con desvergonzada sensualidad.

A Bigas no le gustaba hablar mucho de sus primeros pasos en el mundo del cine. Para el cineasta, el verdadero arranque de su carrera se encontraba claramente en Bilbao, película con la que sorprendió por su frescura formal y su transgresora actitud. Todas sus incursiones fílmicas anteriores no tenían para él mayor interés que el de haber sido el taller donde aprendió los rudimentos básicos de la técnica cinematográfica y se curtió como cineasta. De este modo, a pesar de su marginalidad y su fragilidad argumental, en los cortos eróticos reunidos en Historias impúdicas, en algunos aspectos, se sentaron las bases de un credo erótico, todavía de silueta imprecisa, cuyos temas surgirán con maniática y reiterada fuerza en su filmografía posterior. 


\section{NOTAS}

1 Según datos oficiales que figuran en la base de datos del Ministerio de Cultura. [consulta 15/01/2017. http://www.mecd.gob.es/bbddpeliculas/buscarDetallePeliculas. do?brscgi_DOCN=000001772\&brscgi_ $B C S I D=a 4 c c b d 8 c \&$ language $=e s \& p r e v$ layout=bbddpeliculasResultados\&layou t=bbddpeliculasDetalle]. No obstante, conviene señalar que los datos vertidos por el propio Ministerio se contradicen según las fuentes utilizadas. Así por ejemplo en Películas. Recaudaciones. Espectadores. Boletín informativo del control de taquilla. Datos de 1977, 1978 y 1979, Ministerio de Cultura, 1980, p. 322. Se recogen los siguientes datos: La fecha de licencia de la película es del 10 de enero 1977. La distribuidora PROFILMAR. Número de espectadores hasta diciembre 1977: 10.525 . Recaudación: 1.212 .415 pesetas. No estuvo ni entre las cien películas más taquilleras españolas de ese año. Al año siguiente (1978), se habían sumado 10.368 espectadores más y 864.895 pesetas más. Hasta el 31 de diciembre de ese año la película había acumulado desde su estreno una recaudación de 2.077.310 pesetas. El presupuesto final de la película rondó los quince millones de pesetas.

${ }^{2}$ Declaraciones realizadas por $\mathrm{Bi}$ gas Luna al programa «La edad de oro» presentado por Paloma Chamorro y emitido por TVE entre 1983 y 1985. Parte de esta entrevista forman parte del documental homenaje que la propia televisión le dedicó al director tras su muerte y que, con el título Bigas Luna: El buen anfitrión fue estrenado por la televisión pública en noviembre 2014 dentro de su serie «Imprescindibles». [Consulta 10/01/2017] http://www. rtve.es/television/20141124/bigas-lunabuen-anfitrion/1019932.shtml

${ }^{3}$ I. Pisano, 2001, Bigas Luna. Sombras de Bigas, luces de Luna, Sociedad General de Autores y Editores, Madrid, 2001, p. 160

${ }^{4}$ Bigas no estaría de acuerdo con el teórico Gerard Lenne cuando, en las postrimerías del siglo $\mathrm{XX}$, consideraba trasnochada lo que él denominaba la "distinción sempiterna entre erotismo y pornografía". A su juicio el debate y la discusión habían tenido sentido en los años 60 y 70, una época en la que "los paladines de la moral alanceaban a la pornografía que muestra todo y es vulgar, en nombre del erotismo que no muestra sino sugiere, y que puede por tanto ser elegante y refinado". Para Lenne no se trataba en elegir entre mostrar o sugerir, sino "que hay un tiempo para mostrar, un tiempo para disimular, un tiempo para retrasar y programar el momento de mostrar". Ver G. Lenne, Erotismo y cine, Alcoexport, Madrid,1999, p. 26.

${ }^{5} \mathrm{X}$. Gauthier, Surrealismo y sexualidad, Corregidor, Buenos Aires, 1976, p. 22

${ }^{6}$ Compartimos la opinión de algunos autores que, como Emmanuel Larraz, no dudan en calificar a Bigas Luna como el último surrealista. Ver E. Larraz, "Bigas Luna, le dernier surréaliste", Le cinema de Bigas Luna, Presse Universitaires du Mirail, Toulouse, 2001, pp. 41-52.

${ }^{7}$ X. Gauthier, ídem, p. 42.

${ }^{8} \mathrm{~J}$. M. Martí Font, "Bigas Luna. El erotismo es una tontería", Star, n 51 , 1979, p. 8.

${ }^{9}$ D. Font; J. Batlle; J. Garay, "Entrevista con Bigas Luna", en La mirada, $\mathrm{n}^{\circ}$ 4, 1978, p. 2

${ }^{10}$ J.M. Martí Font, ídem.

${ }^{11} \mathrm{~A}$. Weinrichter, La línea del vientre. El cine de Bigas Luna, Ayuntamiento de Gijón, 1992, p. 87.

${ }^{12}$ Ídem, p. 88.

${ }^{13} \mathrm{M}$. Camí-Vela, "Las dos caras de Bigas Luna: El cineasta y el artista", Arizona Journal of Hispanic Cultural Studies, vol. 4, 2000, p. 262.

${ }^{14}$ I. Pisano, idem, p. 97

${ }^{15} \mathrm{~A}$. Compte-Sponville, Ni el sexo ni la muerte. Tres ensayos sobre el amor y la sexualidad, Espasa Calpe, Barcelona, 2012, p. 154.

${ }^{16}$ Sergio Inestrosa, "Erotismo: consideraciones generales", Chasqui. Revista Latinoamericana de Comunicación, n 57, Ecuador, marzo 1997, p. 41.

${ }^{17}$ A. Sánchez, "El cine en el plato", La fiesta de las imágenes, Festival de cine de Huesca, 1999, p. 91.

${ }^{18} \mathrm{M}$. Fantoni Minnella, Bigas Luna, Gremese Editore, Roma, 2000, p. 43
${ }^{19}$ O. Paz, La llama doble. Amor y erotismo, Seix Barral, Barcelona, 1993, p. 13.

${ }^{20}$ M. Fantoni Minnella, ídem, p. 19.

${ }^{21} \mathrm{M}$. Fantoni Minnella, ídem, p. 13.

${ }^{22} \mathrm{~A}$. Compte-Sponville, idem, $\mathrm{p}$. 161.

${ }^{23}$ V. M. Amela, "A los 60 años morirá Bigas y nacerá Bi", La Contra. Revista de La Vanguardia, 3 agosto 2003, p. 7.

${ }^{24}$ M. Camí-Vela, ídem, p. 254.

${ }^{25} \mathrm{~V}$. M. Amela, ídem.

${ }^{26} \mathrm{G}$. Bataille, El erotismo, Tusquets Editores, Barcelona, 2002, p. 261.

${ }^{27}$ O. Paz, ídem, p. 16.

${ }^{28}$ S. Tabernero, Versión española: Cayetana Guillén Cuervo entrevista a Bigas Luna sobre Caniche, RTVE, 6 diciembre 2002 , [consulta 10/01/2017] https://www.youtube. com/watch?v=jD8hl6kZGhE

${ }^{29}$ L. Soler, 3 paellas con Bigas Luna, Fundación Municipal de Cine-Mostra de Valencia-Ayuntamiento de Valencia, Valencia, 2002, p. 15.

${ }^{30} \mathrm{~J}$. Barreiro, " $i$ Con dos cojones!", Bigas Luna. La fiesta de las imágenes, Festival de cine de Huesca, p. 63.

${ }^{31}$ L. Soler, ídem, p. 30.

${ }^{32}$ La introducción de este guiño aragonés es sorprendente dado que la escena descrita teóricamente transcurre en un hotel de Beverly Hills. Es posible, no lo ponemos en cuestión porque lo desconocemos, que esta cerveza de clase ale tenga una importante proyección internacional, sino fuera así su presencia pudiera ser fruto de la técnica conocida como "emplazamiento publicitario" o bien una broma privada del director.

${ }^{33} \mathrm{~J}$. M. Martí Font, ídem, p. 5.

${ }^{34}$ En realidad, el verdadero nombre de la productora fue CINE PROMOCIÓN. Así al menos figura en los títulos de créditos que abren cada uno de los cortometrajes.

${ }^{35} \mathrm{G}$. Soriano y S. Castelar, Imprescindibles. Bigas Luna, el buen anfitrión, RTVE, 2014, [consulta 15/01/2017]. http://www.rtve.es/television/20141124/bigas-luna-buen-anfitrion/1019932.shtml.

${ }^{36} \mathrm{~J}$. M. Martí Font, ídem, p. 6. 
${ }^{37}$ En la carátula de la edición en video se reproduce el certificado de calificación $n^{\circ}$ 947/84 concedida por el Ministerio de Cultura a través de la Dirección General de Cinematografía a UROS Films para la exhibición pública, distribución y venta de este material audiovisual. El documento está fechado el 24 de abril de 1984 y firmado por la entonces directora general de cinematografía, Pilar Miró. En él se hacen además tres observaciones. En primer lugar, se prohibía la exhibición de este material en locales públicos que no reuniese los requisitos de las salas cinematográficas. En segundo lugar, la cinta se calificaba como exclusivamente para mayores de 18 años y por tanto, sólo podía ser comercializado en locales especiales regulados por el Real Decreto 1189/1982. Y por último, la Dirección General no se responsabilizaba de los posibles cambios de titularidad que de la licencia que no hayan fueran debidamente notificados.

${ }^{38}$ No se ha podido averiguar las razones que motivaron que este título concreto quedara fuera de esta compilación, pero todo apunta a que, casi con toda seguridad, formó parte de la serie original. Es cierto que una entrevista realizada por Octavi Martí para Tele-Express en 1977, Bigas habla sólo de once, pero en el programa La edad de oro de Paloma Chamorro en 1984 habla ya de doce, por lo que nos inclinamos a pensar a que también fue rodado en esta época y debería ser considerado como una más de la serie. Algunas imágenes de este filme aparecen de forma breve en el documental de 2014 que RTVE emitió como homenaje al cineasta bajo el título Imprescindibles. Bigas Luna, el buen anfitrión. También se ha encontrado referencias concretas a este cortometraje en unas declaraciones hechas por el cineasta en 1979 para la revista Star. En ellas contaba el origen y algunas anécdotas de su rodaje: "Un día apareció una pareja para ofrecerse porque hacían un número sexi en un cabaret. Querían que los viera por si me interesaba rodar una película con ellos. Primero me mandaron una foto, ella era una tía rubia y larguirucha, bastante fea. Él era un negro de Ghana. Fui a verlos al hotel donde se hospedaban. Una pensión de mala muerte en las
Ramblas. Cuando llegué a la habitación y me abrieron la puerta resultó que ella tenía anginas, estaba con la bata de boatiné puesta y unos magníficos rulos le coronaban la testa. La habitación era un cuartucho lleno de paquetes desordenados, la radio y la televisión funcionaban al mismo tiempo, a un lado una nevera y la cocina. El enorme negro llevaba una camiseta de Olot. Un panorama encantador. (...) Entonces me montaron su número sexi. Él puso en marcha una casette de la que salió una música y una voz que decía; "Mona y Temba, the most exciting show in the world..." y se pusieron a actuar. Ella con la bata y los chufos y él tal cual. Yo estaba en un rincón absolutamente hipnotizado, con la piel de gallina. Por un lado tenía ganas de reír, mientras por otro aquello me llegaba al fondo. Se me ocurrió filmarlo tal como yo lo había visto. Quedé con ellos un domingo por la mañana. Tan solo con los focos y un angular filmé la misma escena, incluso dejé puesta la televisión por la que salía un programa deportivo. Su número era muy simple, se desnudaban y al ritmo de una música africana se abrazaban" [J. M. Martí Font, ídem, pp. 5-6]

${ }^{39}$ No se han podido localizar las versiones en súper $8 \mathrm{~mm}$ de estas películas, por esa razón la única fuente que hemos tenido a nuestra disposición ha sido a través de la adquisición de una copia de esta edición compilatoria en VHS. Hemos accedido a ellas gracias a la adquisición de una copia en este formato con una calidad en cuanto sonido e imagen suficiente como para hacernos una idea de los contenidos y estética de las cintas originales.

${ }^{40}$ En el caso de Coctel Internacional, las jóvenes bailan al son del tema principal de la película Borsalino (Borsalino, Jacques Deray, 1970) interpretado por la Cuban Latin Band. En Las guitarristas se suceden, sin embargo, varios temas. En primer lugar se escucha Layla cantado por el grupo Derek \& The Dominos, para a continuación dar paso a varios temas de inspiración tahitiana como lo Orana, Valse de Papa y Tamoure, todo ello a cargo de la Orchestra Arthur Iriti.

${ }^{41}$ Ramón Espelt en G. Soriano y S. Castelar, ídem.
${ }^{42} \mathrm{El}$ título de este corto hace referencia al ejemplar del conocido magazine erótico francés Folies de Paris et Hollywood que toma de modelo la protagonista para reproducir ante el espejo las poses de las chicas que aparecen en sus páginas. Esta revista de periodicidad quincenal estuvo publicándose de forma ininterrumpida desde 1947 hasta 1973. En ella se mostraban, a todo color, desnudos de bellas aspirantes a actriz (starlets). Se considera que es la primera publicación de este tipo que se puso a la venta en los quioscos de prensa.

${ }^{43}$ C. Sanabria, "La primera y la última aventura de Bigas Luna: En los lindes de lo marginal", Espiga, $\mathrm{n}^{\circ} 20$, Enero-Junio 2010, 20, p. 107.

${ }^{44}$ Aunque no hay constancia documental que permita confirmar este hecho en el Archivo General de la Administración, en 1979, en una entrevista concedida a la revista Star, cuando hablaba a propósito de estos cortometrajes, el propio Bigas Luna reconocía que, efectivamente, había tenido que lidiar con la censura: "Aún guardo los papeles de censura; porque las mandábamos a censura para que las aprobaran". [J.M. Font, ídem, p. 5]

${ }^{45}$ Mientras se sucede la acción, de fondo, se escuchan los diálogos de dos escenas de la película Raíces Profundas que no son consecutivas. La primera se corresponde con la llegada del personaje de Shane a la granja de los Starrett:

SHANE: ¿Supongo que no le molestará que pase por su propiedad?

JOE STARRETT: No, desde luego.

SHANE: Me dirijo al norte. No esperaba encontrar cercas por aquí. Hola, muchacho. Me vigilabas mientras venía por el camino, ¿ehm?

JOEY: Sí, señor.

SHANE: Así me gusta. El hombre que se acostumbra a ser buen observador llegará siempre a donde se proponga (Se escucha el mugido de unas vacas). Hacía mucho tiempo que no veía una vaca Jersey.

JOE: Pues por aquí verá muchas, Jerseys, Horlteins y de otras razas lecheras. ¿Quiere un poco de agua?

SHANE: Gracias.

JOE: Es usted un poco quisquilloso. 
¿ La segunda pertenece a la pelea que Shane y Joe Starrett mantienen con los secuaces del poderoso ganadero Rufus Ryker en el salón del pueblo y que termina cuando unos de los personajes grita: “ ¡Basta, basta, ¿no me oís? ¡Basta! Ya está bien, pero ¿es que os habéis

vuelto locos? Vais a mataros. Starrett, tú

(1) y Shane volveos a casa. Hacedme caso".
${ }^{46}$ Además de estos temas musicales de carácter cinematográfico, Bigas utilizó en los demás cortos melodías de muy diverso origen en un lúdico popurí donde encontramos desde canciones muy populares en aquel momento como Fernando del grupo ABBA en La deportista o Close To You interpretado por la Moon Light Band en el corto Ski, junto con otras más exóticas como la composición Zhi Yin Meng Li Xun interpretada por el cantante hongkonés Sam Hui que se escucha en el filme París-Hollywood. 


\section{REFERENCIAS}

Amela, V. M. 2003. "A los 60 años morirá Bigas y nacerá Bi." La Contra. Revista de La Vanguardia, August 3, 2003.

Barreiro, Javier. 1999. "¡Con dos cojones!" In Bigas Luna. La fiesta de las imágenes, 61-65. Huesca: Festival de cine de Huesca.

Bataille, Georges. 2002. El erotismo. Barcelona: Tusquets Editores.

Camí-Vela, María. 2000. "Las dos caras de Bigas Luna: El cineasta y el artista." Arizona Journal of Hispanic Cultural Studies 4: 249-263. https://doi.org/10.1353/hcs.2011.0114

Compte-Sponville, Andre. 2012. Ni el sexo ni la muerte. Tres ensayos sobre el amor y la sexualidad-Barcelona: Espasa Calpe.

Fantoni Minnella, Maurizio. 2000. Bigas Luna. Roma: Gremese Editore.

Font, Domenec, Joan Batlle and Jesús Garay. 1978. "Entrevista con Bigas Luna." La mirada 4: 23-24.

Gauthier, Xaviere. 1976. Surrealismo y sexualidad. Buenos Aires: Corregidor.

Inestrosa, Sergio. 1997. "Erotismo: consideraciones generales." Chasqui. Revista Latinoamericana de Comunicación 57 (March): 40-42.

Lenne, Gérard. 1999. Erotismo y cine. Madrid: Alcoexport.

Larraz, Emmanuelle. 2001. "Bigas Luna, le dernier surréaliste." In Le cinema de Bigas Luna, 41-52. Toulouse: Presse Universitaires.

Martí Font, J. M. 1979. “Bigas Luna. El erotismo es una tontería." Star 51: 8.

Martí, Octavi. 1978. "Bigas Luna, pornócrata." Tele/Express, May 6, 1978.
Ministerio de Cultura. "Base de datos." Accessed January 15, 2017. http://www.mecd. gob.es/bbddpeliculas/buscarDetallePeliculas.do?brscgi_DOCN=000001772\&brscgi_ $\mathrm{BCSID}=a 4 c \mathrm{cbd} 8 c$ \&language $=e s \&$ prev_layout =bbddpeliculasResultados\&layout=bbddpelic ulasDetalle.

Paz, Octavio. 1993. La llama doble. Amor y erotismo. Barcelona: Seix Barral, Barcelona.

Películas. Recaudaciones. Espectadores. Boletín informativo del control de taquilla. Datos de 1977, 1978 y 1979. 1980. Madrid: Ministerio de Cultura.

Pisano, Isabel. 2001. Bigas Luna. Sombras de Bigas, luces de Luna. Madrid: Sociedad General de Autores y Editores.

RTVE. 2014. "Imprescindibles. Bigas Luna, el buen anfitrión." Accessed January 15, 2017. http://www.rtve.es/television/20141124/bigas-luna-buen-anfitrion/1019932.shtml.

RTVE. 2002. “Versión española: Cayetana Guillén Cuervo entrevista a Bigas Luna sobre Caniche." Accessed December 6, 2002. https:// www.youtube.com/watch?v=jD8hl6kZGhE.

Sanabria, Carolina. 2010. "La primera y la última aventura de Bigas Luna: En los lindes de lo marginal." Espiga 20 (January-June): 101-115. https://doi.org/10.22458/re.v9i20.1029

Sánchez, Alberto. 1999. "El cine en el plato." In La fiesta de las imágenes. Huesca: Festival de cine de Huesca.

Soler, Lucas. 2002. 3 paellas con Bigas Luna, Valencia: Fundación Municipal de Cine-Mostra de Valencia-Ayuntamiento de Valencia.

Weinrichter, Antonio. 1992. La línea del vientre. El cine de Bigas Luna. Gijón: Ayuntamiento de Gijón. 